\title{
STUDI KOMPARASI PREDIKSI CURAH HUJAN METODE FAST FOURIER TRANSFORMATION (FFT), AUTOREGRESSIVE INTEGRATED MOVING AVERAGE (ARIMA) DAN ARTIFICIAL NEURAL NETWORK (ANN)
}

\author{
Comparation Study on Precipitation Prediction Using Fast Fourier Transformation (FFT), Autoregressive Integrated Moving \\ Average (ARIMA) and Artificial Neural Network (ANN)
}

Dyah Susilokarti', Sigit Supadmo Arif², Sahid Susanto², Lilik Sutiarso²

${ }^{1}$ Direktorat Jenderal Prasarana dan Sarana Pertanian, Kementrian Pertanian,

Jl. R.M. Harsono No. 3 Ragunan - Pasar Minggu, Jakarta Selatan 12550

${ }^{2}$ Jurusan Teknik Pertanian, Fakultas Teknologi Pertanian, Universitas Gadjah Mada,

Jl. Flora No. 1, Bulaksumur, Yogyakarta 55281

Email: dysuka_0668@yahoo.com

\begin{abstract}
ABSTRAK
Kondisi iklim dan ketersediaan air yang optimal bagi pertumbuhan dan perkembangan tanaman sangat diperlukan dalam upaya mendukung strategi budidaya tanaman sesuai ruang dan waktu. Prediksi curah hujan sangat diperlukan untuk untuk mengetahui sejauh mana curah hujan dapat memenuhi kebutuhan air pada setiap tahap pertumbuhan tanaman. Variabilitas curah hujan yang tinggi saat ini, membutuhkan pemodelan yang dapat memprediksi secara akurat bagaimana kondisi curah hujan dimasa yang akan datang. Prediksi yang dilakukan adalah prediksi berdasarkan urutan waktu (time-series). Tujuan dari penelitian ini adalah untuk membandingkan akurasi prediksi curah hujan antara metode Fast Forier Transformation (FFT), Autoregressive Integrated Moving Average (ARIMA) dan Artificial Neural Network (ANN). Kinerja ketiga metode yang digunakan dilihat dari nilai Mean Square Error (MSE). Metode dengan nilai korelasi tertinggi dan nilai MSE terkecil menunjukkan kinerja terbaik. Hasil penelitan untuk FFT diperoleh nilai MSE $=14,92$, ARIMA $=17,49$ sedangkan ANN $=0,07$. Ini menunjukkan bahwa metode Artificial Neural Network (ANN) menunjukkan kinerja yang paling baik diantara dua metode lainnya karena menghasilkan prediksi yang mempunyai nilai MSE terkecil.
\end{abstract}

Kata kunci: Prediksi curah hujan, Fast Forier Transformation (FFT), Autoregressive Integrated Moving Average (ARIMA) dan Artificial Neural Network (ANN)

\begin{abstract}
Optimum climate condition and water availability are essential to support strategic venue and time for plants to grow and produce. Precipitation prediction is needed to determine how much precipitation will provide water for plants on each stage of growth. Nowadays, the high variability of precipitation calls for a prediction model that will accurately foresee the precipitation condition in the future. The prediction conducted is based on time-series data analysis. The research aims to comparethe effectiveness of three precipitation prediction methods, which are Fast Forier Transformation (FFT), Autoregressive Integrated Moving Average (ARIMA) and Artificial Neural Network (ANN). Their respective performances are determined by their Mean Square Error (MSE) values. Methods with highest correlation values and lowest MSE shows the best performance. The MSE result for FFT is 14,92; ARIMA is 17,49; and ANN is 0,07 . This research concluded that Artificial Neural Network (ANN) method showed best performance compare to the other two because it had produced a prediction with the lowest MSE value.
\end{abstract}

Keywords: Precipitation prediction, Fast Forier Transformation (FFT), Autoregressive Integrated Moving Average (ARIMA) and Artificial Neural Network (ANN) 


\section{PENDAHULUAN}

Budidaya tanaman memerlukan strategi yang tepat untuk menyesuaikan variabilitas curah hujan yang tinggi dan ketersediaan air yang optimal bagi pertumbuhan dan perkembangan tanaman. Kondisi iklim ekstrim akibat tingginya variabilitas curah hujan sering terjadi tetapi terlambat diantisipasi sehingga menyebabkan terjadinya gagal panen. Prediksi curah hujan perlu dilakukan menggunakan pemodelan yang dapat memprediksi secara akurat bagaimana kondisi curah hujan dimasa yang akan datang.

Prediksi dilakukan menggunakan analisis deret waktu (time series) yang dapat memberikan informasi tentang adanya kecenderungn (trend), siklus atau fluktuasi disekitar nilai rata-rata jangka panjang, sehingga analisis ini dapat digunakan sebagai alat pemodelan dan prediksi. Terdapat tiga kelompok model yang umum dipakai dalam menganalisis masalah - masalah cuaca dan iklim yaitu model deterministik, parametrik dan stokastik. Model deterministik murni dapat diperoleh dengan mengikut sertakan seluruh hubungan hubungan teoritis dari suatu kejadian sedangkan model stokastik diperoleh dengan menggunakan data percobaan untuk menghasilkan keluaran yang hanya dapat diduga dengan pengertian statistik, yaitu penggunaan data yang sama akan menghasilkan keluaran yang berbeda mengikuti pola statistik tertentu (Bey, 1991 dalam Askari dan Bey, 2000).

Penelitian ini menggunakan 3 (tiga) model stokastik yaitu FFT (Fast Fourier Transformer), ARIMA (Autoregressive Integrated Moving Average) dan ANN (Artificial Neural Network). Analisis FFT digunakan untuk mengetahui hubungan atau korelasi antara siklus/frekuensi terhadap besaran amplitudonya. Periodogram data curah hujan yang dihasilkan analisis FFT menunjukkan besarnya data untuk masing-masing siklus, sehingga melalui siklus yang dihasilkan menunjukkan tingkat proritas yang akan digunakan dalam model prakiraan curah hujan. Metode FFT, memiliki kemampuan yang hampir sempurna dalam memodelkan pola dari parameter terukur dalam satu periode tertentu. Metode ini menerapkan model yang sinusoidal, dimana akan menghasilkan nilai prediksi yang sama untuk setiap waktu ( $\boldsymbol{t}$ ) pada periode mana pun.

Autoregresif Integrated Moving Average (ARIMA) sering disebut metode runtun waktu Box-Jenkins adalah model yang menggunakan nilai masa lalu dan sekarang dari variabel dependen untuk menghasilkan peramalan jangka pendek yang akurat, sangat baik digunakan untuk melihat pola masa lampau dan kemudian merepresentasikan pola masa yang akan datang untuk memprediksinya. Bey (2003) mengatakan bahwa ARIMA adalah metode stokatik yang sangat bermanfaat untuk membangkitkan proses/data deret waktu dimana setiap kejadian saling berkorelasi.
Artificial Neural Networ (ANN) merupakan sistem pemrosesan informasi yang didesain dengan menirukan cara kerja jaringan syaraf otak manusia yang diimplemintasikan dengan menggunakan program komputer yang mampu menyelesaikan sejumlah proses perhitungan selama proses pembelajaran, karena memiliki kemampuan belajar terhadap informasi numerik melalui algoritma pembelajaran dan kemampuan pengenalan pola (Kusumadewi, 2003). ANN mampu melakukan pengenalan kegiatan berbasis data masa lalu sehingga mampu memberikan keputusan terhadap data yang belum pernah dipelajari.

Askari dan Bey, (2000); Dupe, (1999); Estiningtyas dan Amien, (2006) telah mengembangkan model prakiraan curah hujan dengan pendekatan analisis keterkaitan antar waktu maupun keterkaitan antar ruang menggunakan regresi, ARIMA, analisis FFT, dan analisis Kalman Filter. Modelmodel yang disusun umumnya menggambarkan adanya ketidakseimbangan antara aspek analisis ruang (spatial analysis) dengan analisis deret waktu (time series analysis). Model-model peramalan deret waktu umumnya cenderung tidak tajam dalam membahas aspek keterkaitan ruang. Sebaliknya pada model-model prakiraan yang menggunakan analisis keterkaitan ruang antar stasiun atau analisis hubungan antar parameter umumnya diterapkan pada satu periode waktu tertentu dan mengabaikan keterkaitan deret waktu (Pramudia, 2008).

Model peramalan curah hujan yang menerapkan keterkaitan deret waktu dengan keterkaitan ruang antar stasiun atau keterkaitan dengan parameter iklim dan parameter fisik lainnya sudah dikembangkan Halide dan Ridd (2000) dengan memanfaatkan teknik ANN yang mampu menggabungkan aspek analisis waktu dan ruang secara simultan pada bidang hidrologi. Mahdi dan Suerborn (2002) melakukan analisis terhadap keragaman curah hujan jangka panjang di Ethiopia yang menunjukkan kecenderungan curah hujan menurun selama abad 20. Sipayung, dkk. (2003), melakukan analisis deret waktu pada data curah hujan di Indonesia dan hasilnya menunjukkan bahwa puncak curah hujan Indonesia sebagian besar didominasi oleh annual oscillation dan terdapat juga daerah-daerah yang didominasi oleh semi annual oscillation dan fenomena ENSO (El Niño Southern Oscillation). Valipour, M. (2012) melakukan kalibrasi model time series menggunakan Auto Regresif Integrated Moving Average (ARIMA), Auto Regresi Moving Average (ARMA), Auto Regresif (AR) dan Moving Average (MA) dengan membandingkan $\mathrm{R}^{2}$ model, untuk peramalan curah hujan dalam iklim semi-arid dengan kesimpulan akurasi model time series meningkat untuk data observasi yang lebih panjang. Nanda, dkk. (2013). Menggunakan Model ARIMA $(1,1,1)$ dengan membandingkan model pembelajaran ANN yang berbeda untuk analisis data curah hujan, antara lain 
Multi Layer Perceptron (MLP), Functional-link Artificial Neural Network (FLANN) and Legendre Polynomial Equation (LPE). Hasil penelitian menunjukkan bahwa Flann memberikan hasil prediksi yang lebih baik dibandingkan dengan model ARIMA $(1,1,1)$ dengan nilai Absolute Average Percentage Error (AAPE) yang lebih kecil.

Tujuan dari penelitian ini adalah untuk membandingkan akurasi prediksi curah hujan menggunakan metode Fast Forier Transformation (FFT), Autoregressive Integrated Moving Average (ARIMA) dan Artificial Neural Network (ANN). Studi kasus di wilayah selatan Jatiluhur Kabupaten Subang. Tingkat akurasi dinilai berdasarkan kinerja ketiga metode yang digunakan dilihat dari nilai Mean Square Error (MSE). Metode dengan nilai MSE terkecil menunjukkan kinerja terbaik.

\section{METODE PENELITIAN}

\section{Lokasi}

Lokasi penelitian adalah beberapa Daerah Irigasi (DI) di wilayah selatan Jatiluhur yaitu DI. Curugagung, DI. Cileuleuy, DI. Cinangka dan DI. Pangsor. Lokasi dipilih karena merupakan daerah irigasi yang tidak mendapatkan suplesi dari bendungan Jatiluhur dan hanya mengantungkan ketersediaan air dari sumber setempat sehingga rencana penelitian selanjutnya tentang pembuktian dampak perubahan iklim terhadap ketersediaan air pada lokasi penelitian dapat terpenuhi.

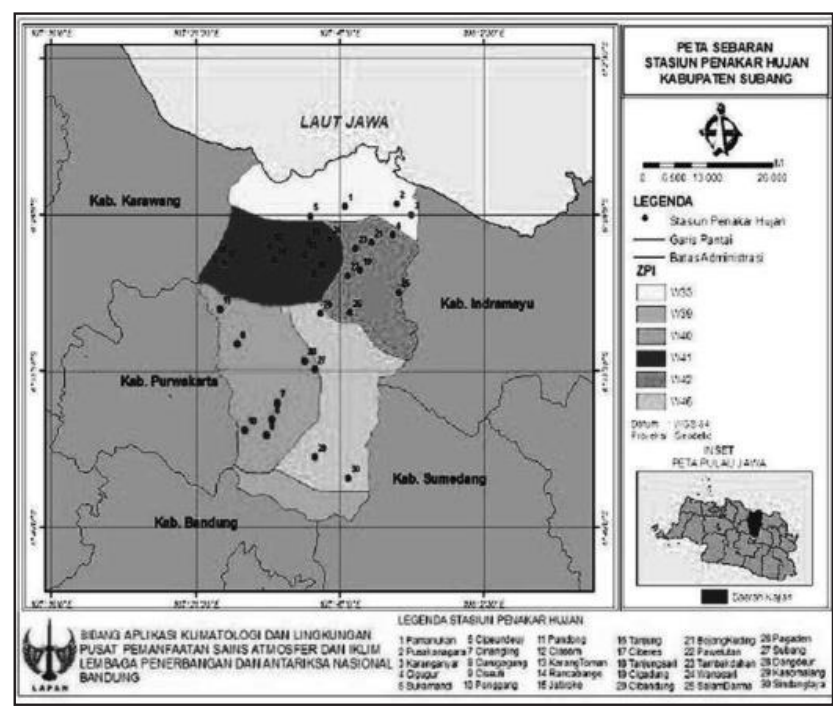

Gambar 1. Lokasi penelitian dan stasiun curah hujan

\section{Data dan Perangkat Lunak}

Penelitian ini menggunakan data curah hujan bulanan periode tahun 1975 - 2012. Data diperoleh dari 6 (enam) stasiun curah hujan disekitar lokasi penelitian yaitu stasiun: (1) Kalijati; (2) Curugagung; (3) Cinangling; (4) Dangdeur; (5) Subang dan (6) Pegaden. Data diperoleh dari Lanud Suryadharma Kalijati dan Divisi III Perum Jasatirta II Kabupeten Subang. Alat yang digunakan dalam penelitian ini adalah seperangkat komputer dengan software MATLAB versi 2010a untuk menganalisis ANN, SPSS 16 untuk menganalisis FFT dan ARIMA, Microsoft exel untuk entri data dan Microsoft word 2007 untuk penyajian makalah.

\section{Langkah Analisis}

Langkah analisis dilakukan dengan tahapan sebagai berikut :

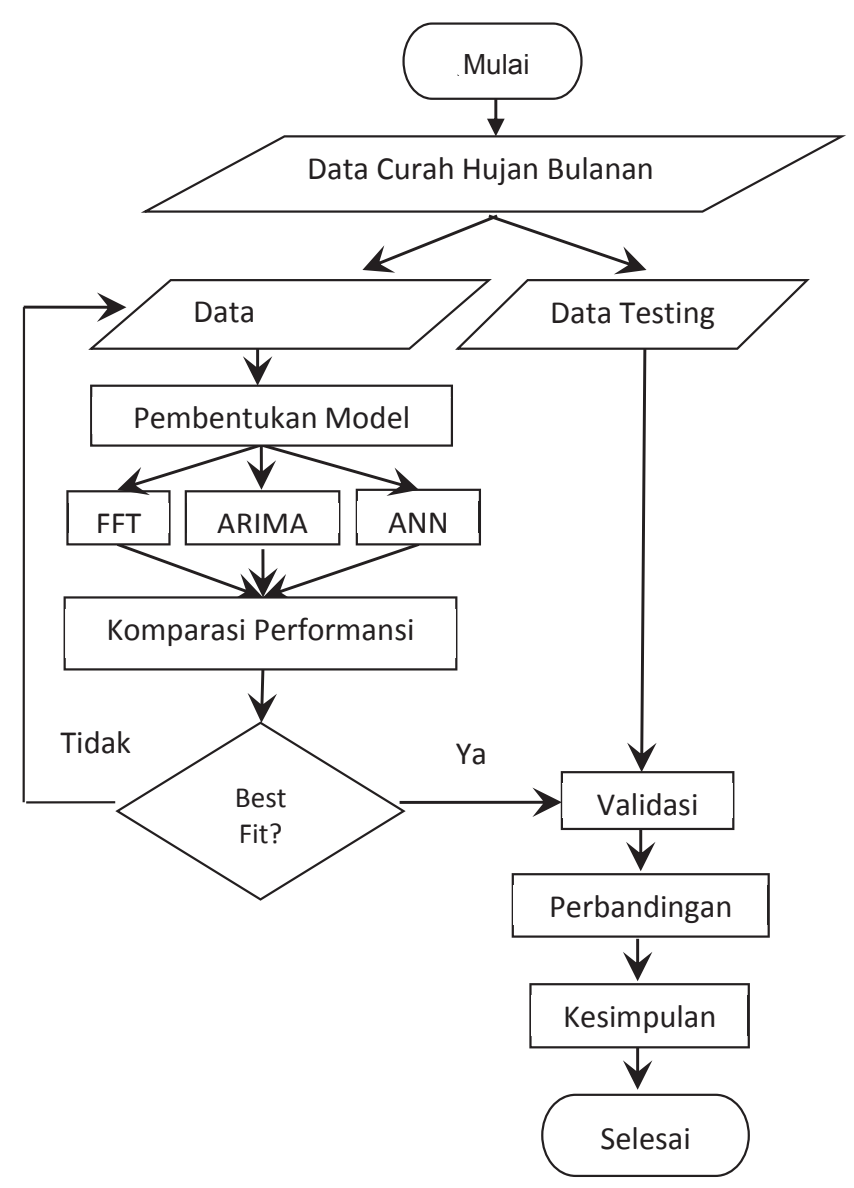

Gambar 2. Alur penelitian

\section{HASIL DAN PEMBAHASAN}

\section{Analisis Metode Fast Fourier Transform (FFT)}

Prediksi curah hujan menggunakan FFT dilakukan dengan menggunakan data curah hujan 5 tahun untuk memprediksi data 5 tahun berikutnya. Persamaan terbaik yang diperoleh dengan $\mathrm{MSE}=14,92$. dengan tingkat kepercayaan dalam pemodelan adalah $95 \%$. 


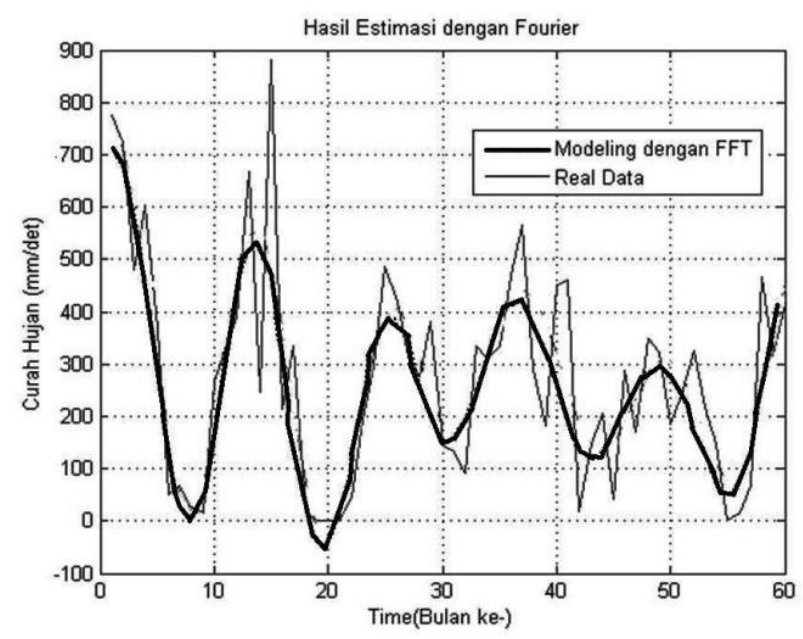

Gambar 3. Model FFT untuk prediksi curah hujan 5 tahun

Hasil prediksi menunjukkan terbuka kemungkinan untuk memodelkan data curah hujan dengan FFT sebagai analisis waktu tetapi, FFT lebih cenderung diaplikasi sebagai tools analisis dibandingkan predictor tunggal yang notabene mengestimasi data-data non linear.

\section{Analisis Metode Autoregressive Integrated Moving Average} (ARIMA) (p,d,q)

\section{Uji Stasioneritas}

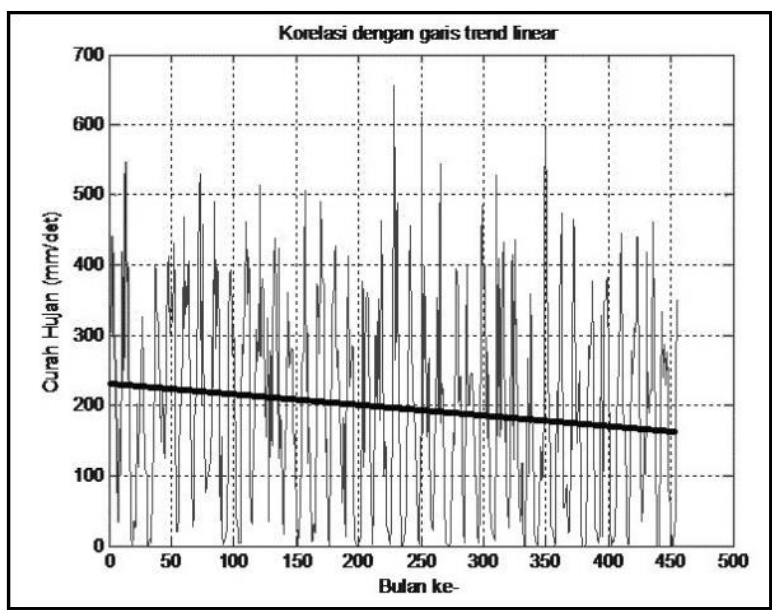

Gambar 4. Data curah hujan dengan trend menurun

Hasil analisis awal data curah hujan selama 38 tahun menunjukkan adanya trend yang bergerak turun. Trend menunjukkan bahwa data tersebut tidak stasioner sehingga sebelum dijadikan data untuk analisis prediksi, data curah hujan harus ditrasformasi menjadi data yang stasioner. Untuk menghilangkan sebuah trend, mengunakan teknik differencing orde ke 1 dan menghasilkan data seperti pada Gambar 4.

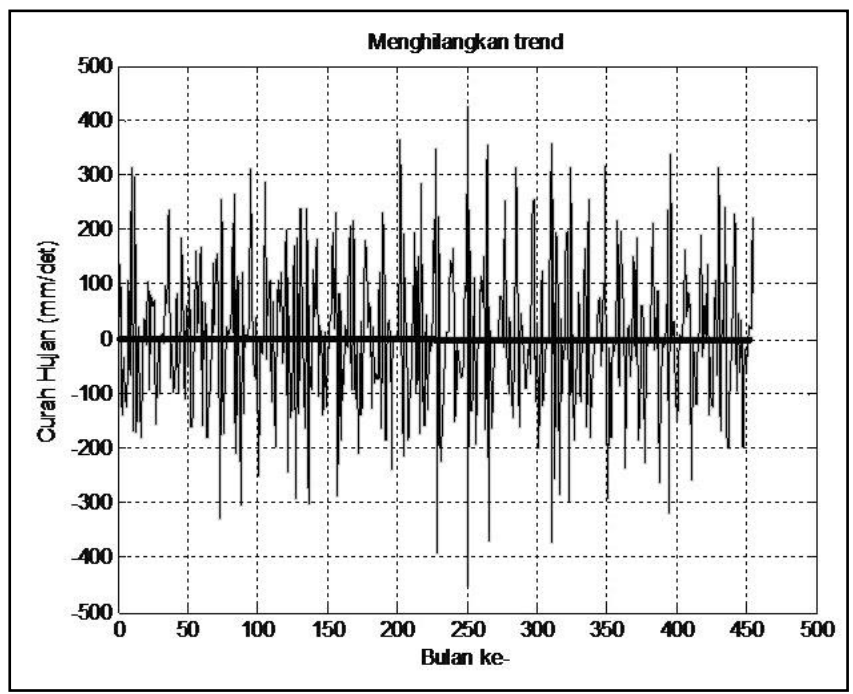

Gambar 5. Data curah hujan yang sudah stasioner

Berdasarkan analisis correlogram maka untuk data Curah Hujan wilayah Tahun 1975-2012. dengan differencing (d) $=1$ data sudah stasioner.

\section{Analisis colleogram (ACF dan PACF)}
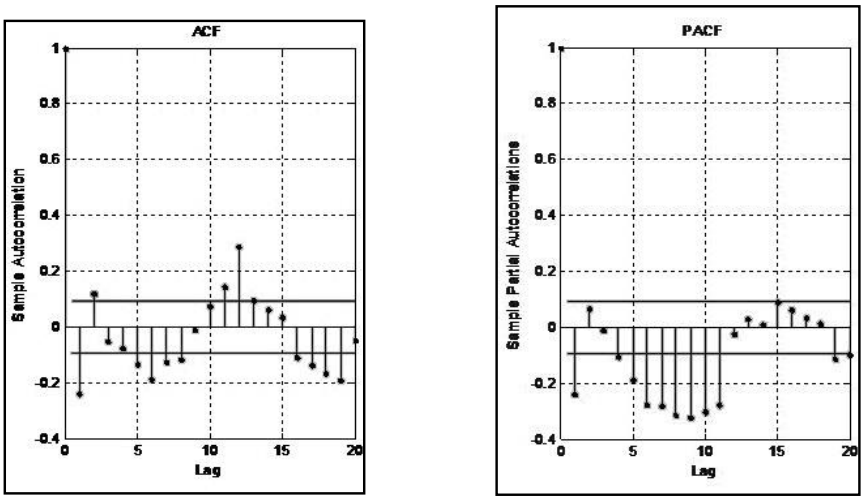

Terlihat ACF langsung putus pada lag ke 1, demikian juga untuk PACF.

Gambar 6. Analisis colleogram (ACF dan PACF)

Hasil analisis awal data curah hujan wilayah diperoleh orde ARIMA (p,d,q) untuk model yang prediksi curah hujan sebagai berikut :

a. $\quad \mathrm{p}=1$, diperoleh berdasarkan plot ACF untuk data dengan differencing 1 dimana ada satu koefisien yang signifikan, yaitu pada lag 1 .

b. $d=1$, proses pembedaan yang dilakukan sehingga didapatkan stasioner adalah differencing sebanyak 1 kali. Sehingga nilai $\mathrm{d}=1$.

c. $\mathrm{q}=1$, terlihat berdasarkan plot PACF untuk data dengan differencing 1 dimana ada satu koefisien yang signifikan, yaitu pada lag 1 . 
Melalui proses identifikasi, penaksiran dan pengujian, diperoleh model sementara dari plot data curah hujan adalah model ARIMA $(1,1,1)$, ARIMA $(0,1,1)$, ARIMA $(0,1,0)$, dan $\operatorname{ARIMA}(1,1,0)$.

Tabel 1. Ukuran kebaikan model secara statistik

\begin{tabular}{lcccc}
\hline \multirow{2}{*}{$\begin{array}{c}\text { Kecepatan } \\
\text { Model }\end{array}$} & \multicolumn{4}{c}{ Model ARIMA } \\
\cline { 2 - 5 } & $(0,1,1)$ & $(0,1,0)$ & $(1,1,0)$ & $(1,1,1)$ \\
\hline RMSE & 134,57 & 137,98 & 134,01 & 133,91 \\
MAPE & 531,94 & 437,84 & 390,03 & 254,45 \\
MAE & 103,90 & 103,45 & 103,45 & 102,82 \\
\hline
\end{tabular}

Nilai Error yang dihasilkan model ARIMA $(1,1,1)$ paling kecil dibanding model lainnya.

Model prediksi ARIMA (p,d,q) di atas memberikan hasil forecasting yang berbeda-beda. Untuk itu dipilih satu model yang memenuhi kriteria baik secara statistik, artinya model tersebut bisa dengan tepat secara statistik meramalkan curah hujan sesuai dengan data sesungguhnya.

Berdasarkan nilai RMSE, MAPE dan MAE, maka model yang memberikan nilai penyimpangan terkecil adalah ARIMA(1,1,1), Sehingga dipilih model ARIMA(1,1,1). Model ARIMA(1,1,1) kemudian digunakan untuk proses prediksi data curah hujan 5 tahun. Diperoleh hasil terbaik dengan $\mathrm{MSE}=17,49$.

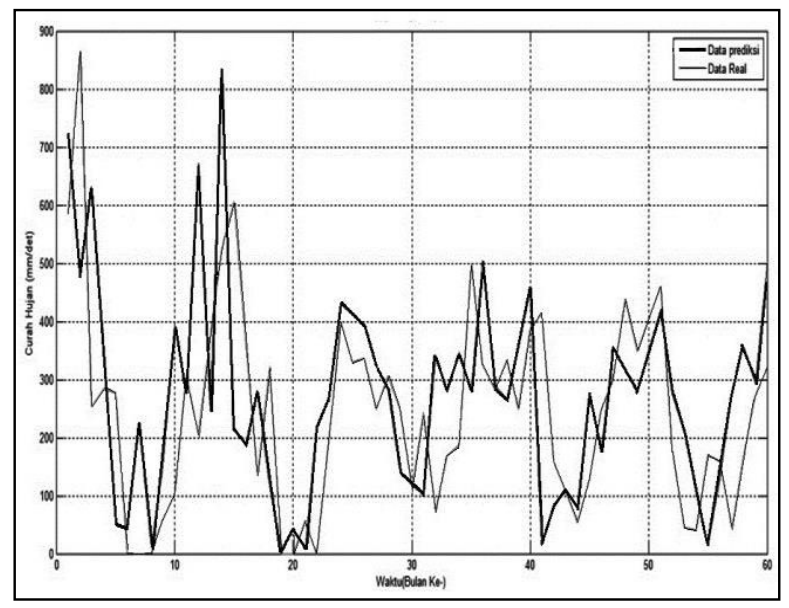

Gambar 7. Model ARIMA untuk prediksi curah hujan 5 tahun

Hasil Prediksi membuktikan bahwa metode ini cukup baik dalam memprediksi suatu deret data tetapi metode ini mempunyai kelemahan karena tidak mampu memprediksi untuk periode yang panjang, karena semakin jauh memprediksi hasilnya semakin konstan mendekati nilai tertentu (umumnya semakin mendekati nilai tengahnya).

\section{Analisis Metode Artificial Neural Network (ANN)}

Prediksi curah hujan menggunakan metode Artificial Neural Network (ANN) Backpropagation memperoleh nilai terbaik arsitektur jaringan adalah 1-20-2 yaitu 1 input layer berisi data curah hujan 20 hidden layer, dan 1 output berisi data curah hujan hasil prediksi dengan nilai MSE 0,001.

Performa pengujian/validasi data dapat dikenali dengan baik sesuai hasil pengujian MSE $=0.0129$. Tahap testing menggunakan metode feedforward (langkah maju) dengan arsitektur 1-20-1, learning rate $(\alpha)=0,9$. Tahap testing tersebut menghasilkan nilai kuadrat error sebesar 0.0116 . Hasil pengujian model untuk mengetahui performa ANN ditunjukkan pada Gambar 1. Dengan $\mathrm{R}^{2}=0,717$.

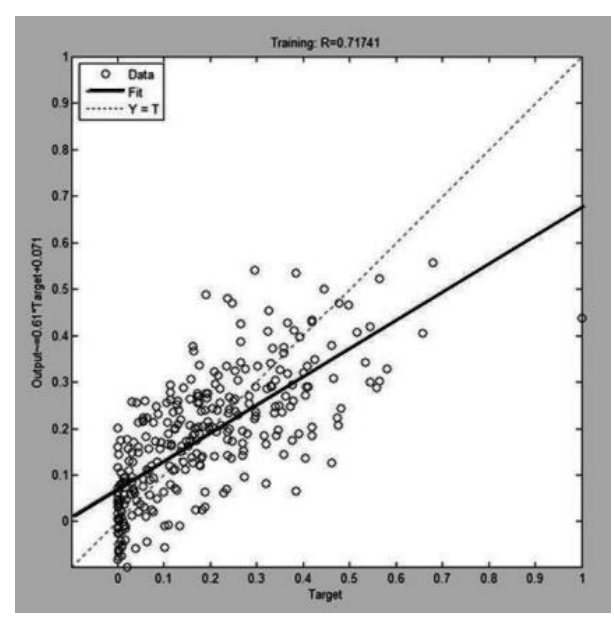

Gambar 8. Performa ANN tahap pengujian (testing)

Model yang telah didapatkan digunakan untuk memprediksi curah hujan. Data yang digunakan sebagai input adalah data tahun sebelumnya. Prediksi menggunakan input data yang telah dimiliki dan kemudian dibandingkan dengan data yang sebenarnya. Hasil prediksi menunjukkan error yang cukup baik yaitu MSE=0.07.

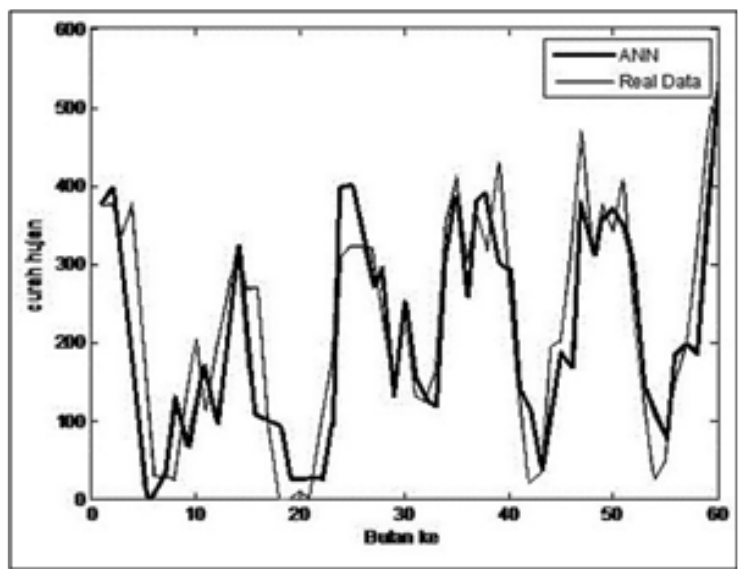

Gambar 9. Model ANN untuk prediksi curah hujan 5 tahun 


\section{Analisis Tiga Metode Prediksi Curah Hujan}

Hasil prediksi curah hujan menggunakan metode FFT, ARIMA dan ANN dapat dilihat di bawah ini.

Tabel 2. Komparasi performa model FFT Vs ARIMA Vs ANN

\begin{tabular}{ccc}
\hline No. & Metode & MSE \\
\hline 1 & FFT & 14,92 \\
2 & ARIMA $(1,1,1)$ & 17,49 \\
3 & ANN - (Backpropagation) & 0,07 \\
\hline
\end{tabular}

Masing-masing metode yang digunakan memiliki kelebihan dan kekurangan masing-masing. Metode FFT, memiliki kemampuan yang hampir sempurna dalam memodelkan pola dari parameter terukur dalam satu periode tertentu. Metode ini menerapkan model yang sinusoidal, sehingga akan menghasilkan nilai prediksi yang sama untuk setiap waktu t pada periode mana pun. Pada kenyataannya, fluktuasi curah hujan sangat acak dan akan memiliki nilai yang berbeda dan acak meskipun pada waktu t yang sama pada periode yang berbeda. Sehingga teknik ini pun sangat berpotensi menghasilkan bias yang tidak kecil. Metode ini masih cendrung lemah jika digunakan untuk melakukan peramalan dengan prediksi yang dihasilkan memiliki error yang tidak saling bebas satu sama lain (autokorelasi). Suatu data curah hujan dapat memiliki pola yang sama untuk setiap periodenya tetapi fluktuasinya pasti berbeda pada setiap periodenya.

Metode ARIMA merupakan pengembangan lebih lanjut dari model Autoregressive Moving Average (ARMA) yang berdasar pada konsep regresi linier dan keterkaitan antar waktu terhadap data yang berurutan. Metode ARIMA dapat digunakan untuk analisis data deret waktu dan peramalan data. Metode ini memerlukan penetapan karekteristik data deret berkala seperti stasioner, musiman dan sebagainya yang memerlukan suatu pendekatan sistematis dan akhirnya akan menolong untuk mendapatkan gambaran yang jelas mengenai model - model dasar yang akan ditangani. Kelemahan model autoregresif atau moving average seperti ini adalah tidak mampu memprediksi untuk periode yang jauh ke depan, karena semakin jauh memprediksi hasilnya semakin konstan mendekati nilai tertentu, umumnya semakin mendekati nilai tengahnya.

ANN dalam time series relatif lebih mudah dalam perkembangannya dan implementasinya. Hal ini terutama didasarkan pada kemampuan ANN untuk prediksi data non linear. Konfigurasi arsitektur pada ANN dapat mengatasi beberapa non linearitas data, sehingga konvergensi dapat dihindari, walau masih menggunakan data yang dilatih dengan tingkat kesalahan rata-rata kudrat $(\mathrm{MSE})=0.07$, tapi perubahan pola dapat dikenali oleh ANN. Hal ini disebabkan adanya fase propagasi balik saat pelatihan, sehingga sinyal informasi jauh lebih kaya dengan pola-pola data non linearnya. Apriyanti (2005) menggambarkan bahwa teknik ANN baik diterapkan pada model prakiraan curah hujan yang memfokuskan pada aspek skala waktu dan skala ruang secara bersamaan.

\section{KESIMPULAN}

Hasil studi komparasi tiga metode prediksi curah hujan di peroleh kesimpulan sebagai berikut :

1. Performa dari ketiga metode yang digunakan dilihat dari standarisasi MSE (Mean Square Error) sebagai standar perhitungan deviasi perbedaaan antara data real dan data pemodelan. Untuk FFT diperoleh nilai MSE = 14,92, ARIMA MSE= 17,49 sedangkan ANN diperoleh hasil $\mathrm{MSE}=0,07$. Sehingga metode dengan performa terbaik yang dipilih berdasarkan hasil MSE nya yaitu model ANN dengan hasil MSE terkecil dibandingkan dengan metode FFT atau ARIMA.

1. Metode FFT, memiliki kemampuan yang hampir sempurna dalam memodelkan pola dari parameter terukur dalam satu periode tertentu, tetapi metode ini masih cendrung lemah jika digunakan untuk melakukan peramalan dengan prediksi yang dihasilkan memiliki error yang tidak saling bebas satu sama lain (autokorelasi).

2. Metode ARIMA menganalisis keterkaitan waktu, hasil peramalan dari metode ini memiliki pola dasar yang sama setiap periodenya dengan fluktuasi yang cenderung sama, dimana fluktuasi yang dihasilkan tersebut terikat dengan pola dasarnya. Kelemahan model ARIMA adalah tidak mampu memprediksi untuk periode yang jauh ke depan, karena semakin jauh memprediksi hasilnya semakin konstan mendekati nilai tertentu, umumnya semakin mendekati nilai tengahnya.

3. Model ANN sebagai model analisis runtun waktu untuk prediksi curah hujan hasilnya lebih baik dibanding metode FFT dan ARIMA dari segi performa dan kehandalan dalam memprediksi waktu yang akan datang yang bersifat nonlinear.

\section{DAFTAR PUSTAKA}

Apriyanti, N. (2005). Optimasi Jaringan Syaraf Tiruan dengan Algoritma Genetika untuk Peramalan Curah Hujan. Skripsi. Departemen Ilmu Komputer. Fakultas Matematika dan Ilmu Pengetahuan Alam. Institut Pertanian, Bogor. 
Askari, M. dan Bey, A. (2000). Analisis Deret Waktu (Analisis Data Iklim dengan Metode Box-Jenkins). Bahan Praktikum Metode Klimatologi pada Program Pencangkokan Agroklimatologi. Jurusan Geofisika dan Meteorologi. Fakultas Matematika dan Ilmu Pengetahuan Alam. Institut Pertanian Bogor, Bogor.

Bey, A. (2003). Prospek model ARIMA sebagai alat prediksi curah hujan Stasiun Karawang sebagai kasus dalam Ratag (Ed). Prediksi cuaca dan iklim. Prosiding Temu Ilmiah Nasional di Lembaga Penerbangan dan Antariksa Nasional, Bandung 2002.

Dupe, Z.L. (1999). Prediction Nino-3.4 SST anomaly using simple harmonic model. Paper presented at the Second International Conference on Science and Technology for the Assessment of Global Climate Change and Its Impact on Indonesian Maritime Continent, 29 November-1 Desember 1999.

Estiningtyas, W. dan Amien, L.I. (2006). Pengembangan model prediksi hujan dengan metode filter kalman untuk menyusun skenario masa tanam. Jurnal Sumber Daya Lahan 10(2): 1-18.

Halide, H. dan Ridd, P. (2000). Modeling inter-annual variation of local rainfall data using a fuzzy logic technique, International Forum on Climate Prediction, Agriculture and Development, James Cook Univ. 26-28 April 2000, Australia: IRI, 2000.
Kusumadewi, S. (2003). Artificial Intelligence: Teknik dan Aplikasinya. Edisi Pertama, Cetakan Pertama, Graha Ilmu, Yogyakarta

Nanda, S.K., Tripathy, D.P., Nayak, S.K. dan Mohapatra, S. (2013). Prediction of rainfall in India using artificial neural network (ANN) models. International Journal of Intelligent Systems and Applications 12 :122.

Mahdi, O. dan Suerborn, P. (2002). A Preliminiary assessment of characteristics and long term variability of rainfall in Ethiopia - basis for suistainable land use and resource management, in Proceeding of Conference of International Agriculture research for Decelopment, Witzenhausen, Oktober 9-11.

Pramudia, A. (2008). Pewilayahan Hujan dan Model Prediksi Curah Hujan untuk Mendukung Analisis Ketersediaan san Kerentanan Pangan di Sentra Produksi Padi. Disertasi. Sekolah Pascasarjana Institut Pertanian Bogor, Bogor.

Sipayung, B.S., Hariadi, T.E, Nurzaman, A. dan Hermawan, E. (2003). The spectrum analysis of rainfall in Indonesia. Indonesian Journal of Physics 14: 3.

Valipour, M. (2012). Number of required observation data for rainfall forecasting according to the climate conditions. American Journal of Scientific 74: 79-86. 